\title{
O biograficznym kontekście Mickiewiczowskich deziluzji miłosnych
}

\section{About the Biographical Context of Mickiewicz's Disappointments in Love}

To some extent Mickiewicz's biography was already formed and turned into a myth by the poet's son and his other apologetic researchers. During this process some of the documents were destroyed which resulted in the reduction of important contexts. However, the article actually shows one of these contexts and describes a VilniusKaunas period of the poet's life, especially his mental dilemmas after parting ways with Maria Puttkamer, de domo Wereszczak.

Her presence in the biography and works of Adam Mickiewicz was a result of a strong, mutual feeling. This affection is seen by the researches as an archmodel of romantic love, our Polish Werter's paradigm. It was nothing more than presuppositions based mostly on Mickiewicz's works that created the myths and legends around the poet's acquaintance with Puttkamer. After finding some crucial documents, such as birth and death registration acts of Helena, the Puttkamer's daughter, it is possible to enrich the interpretation of the letter correspondence and therefore to see the poet's texts through the slightly different, biographical prism.

Keywords: Adam Mickiewicz, Maria Puttkamer, née Wereszczak, love poetry, Dziady part IV and III

* Dorota Samborska-Kukuć (orcid: 00oo-ooo2-1943-6694) - prof. zw. dr hab., kierownik Zakładu Literatury Pozytywizmu i Młodej Polski Instytutu Filologii Polskiej i Logopedii Uniwersytetu Łódzkiego, kontakt: ddsk@wp.pl. 
$\neg$ rudno w dziejach literatury polskiej wskazać innego niż Adam Mickie1 wicz pisarza, który będąc jednocześnie niekwestionowaną reprezentacją rodzimej duchowości („my z niego wszyscy”), jej długim trwaniem („sto lat nas karmi ten chleb"), ikoną artyzmu słowa, który doczekał się osobnej, wciąż otwartej biblioteki z tysiącami opracowań interpretacyjnych i biograficznych, został w dużej mierze spetryfikowany i w pewnym sensie sprowadzony do mitu. Chciano mieć Mickiewicza pomnikowego, nienaruszalnego, monolitycznego, bez szczelin i rozwarstwien - takim stworzył go syn Władysław, takim utrwalali badacze-apologeci: m.in. Władysław Bełza czy Józef Kallenbach. Za cenę posądzenia o naiwność, a nawet śmieszność wymyślano i snuto historie urągające prawdopodobieństwu, lekceważono i co gorsza - niszczono dokumenty (listy, wspomnienia), pokazujące Mickiewicza jako człowieka pośród ludzkich namiętności w dniu jego powszednim. Władysław Mickiewicz był pierwszym biografem swego ojca i mimo wielu zasług, jakie na tym polu położył, eliminował wszystko to, co mogło rzucić cień na świetlaną postać Wieszcza tak, jak gdyby ten rzekomy cień miał poetę zniekształcić, pomniejszyć, zbanalizować w oczach potomności. W ten sposób redukował konteksty.

Nie można zatem dziwić się temu, że gorączkowym i totalnym w zamierzeniu zabiegom impregnowania Mickiewiczowskiego mitu musiał towarzyszyć sceptycyzm pragmatystów. Mit maskuje bowiem rzeczywiste, a eksponuje fantastyczne, pogardza typowością, a odwołuje się do fantazmatów. Gładkość, okrągłość, kompletność, skończoność jako cechy biografii z wyraźnymi idiomami kulturowymi, przeważnie wzbudzają podejrzenie o uproszczenia i mistyfikacje. Odbiorca wyczuwa tonację mitu i traci zainteresowanie tematem - być może właśnie dlatego, jak pisał Czesław Miłosz, „dla młodych pokoleń polskich Mickiewicz jest jedynie zabytkiem zmurszałego patriotyzmu"1. Skutecznym rodzajem przeciwdziałania „batalii o nieautentyczność" poety mogła stać się rzetelna weryfikacja. Proces dekonstruowania mickiewiczowskiego kultu z użyciem różnych narzędzi rozkruszania rozpoczął Tadeusz Żeleński-Boy, czołowy ikonoklasta i demaskator rozmaitych konfabulacji i kamuflaży biograficznych (nie tylko przecież Mickiewiczowskich), ale metoda tych odtajnień, ich sensacyjny cel, a zwłaszcza niepewne wnioski, jakie Boy usiłował forsować, mające

1 C. Miłosz, O podróżach w czasie, wybór i oprac. J. Gromek, Kraków 2004, s. 16. 
charakter alogicznego ignotus per ignotum, wywołują sprzeciw, bo nie przekonują konkretnymi świadectwami. Autor Brązowników (1930), jako śledczy prowadzący proces poszlakowy po latach, kieruje się intuicją i domniemaniem, bo układ faktów wydaje mu się fantastyczny, ale sam nierzadko preparuje dowody, by uzasadnić swoje tezy (m.in. teorie o żydowskim pochodzeniu Ksawery Deybel). Współcześnie odbrązawia, ale również mityzuje Mickiewicza Jarosław Marek Rymkiewicz. W Żmucie i Bakecie - książkach z mickiewiczowskiego cyklu Jak bajeczne żurawie - rozważa hipotezy, mnoży wyobrażenia i wizje, niekiedy wkraczając nawet na terytorium profanum.

Portret wieszcza, jaki wyłania się z twórczości Rymkiewicza, jest [...] rezultatem swoistego mariażu rzeczywistości i wyobraźni, faktu i legendy, tego, co uznano za prawdę, z tym, co można by za prawdę uznać. [...] Rymkiewicz ukazuje Mickiewicza jako ojca nieślubnego dziecka, co wybitnie nie pasuje do jego tradycyjnego wizerunku. Mickiewicz w omawianym cyklu wyraźnie umyka z romantycznej formy, nie przystaje do niej, nie jest jej wzorowym modelem ${ }^{2}$

- trafnie komentuje Rymkiewiczowską kreację Danuta Ryszka. Jaki zatem Mickiewicz wyłania się z eseistyki autora Żmuta? Anna Nasiłowska we wstępie do „romantycznego” zeszytu „Tekstów Drugich” zdaje się komentować ten rodzaj odkształcania:

Odbrązawianie nie ma wielkich szans. Wręcz przeciwnie, mam wrażenie, że historykom literatury często chodzi o poszukiwania i przymiarki do nowego, skutecznego sposobu nałożenia czegoś, co mogłoby zastąpić pomnikową patynę. Mickiewicz tak żywy, jak to tylko jest możliwe w wypadku historycznych postaci - oto ideał tej prozy ${ }^{3}$.

Ideałem byłoby jednak wskrzeszanie poprzez wyzyskiwanie autentycznych, niespreparowanych świadectw, by mogły żyrować prawdę, uwzględnienie kontekstów, także tych zaniedbanych, peryferyjnych oraz pragmatyzm jako metoda rekonstrukcji wolna od pokus idealizujących i od repetycji dawnych

2 D. Ryszka, Poeta o poecie. Mickiewicz na warsztacie Rymkiewicza, w: W cieniu Mickiewicza, red. J. Lyszczyna, M. Bąk, Katowice 2006, s. 347, 349.

3 A. Nasiłowska, Płaszcz Konrada, „Teksty Drugie”, 1993, z. 2, s. 3-4. 
formuł. Z pewnością ucierpi na tym gładkość biografii poety, odsłonią się pęknięcia i szczeliny, a fragment zastąpi kompleksowość ciągów, być może jednak życiorys Mickiewicza stanie się bardziej wiarygodny.

Jedną z pułapek kreacyjnych było potraktowanie Mickiewicza jako mężczyzny nadzwyczaj kochliwego, znacznie przekraczającego miarę fascynacji kobiecością. Skłonność tę formowano przeważnie jako wariant platoniczny, duchowy, a nawet Werterowski, wierząc, że da się uniknąć kłopotliwych asocjacji erotycznych. Dotyczyło to zwłaszcza, a może przede wszystkim, pierwszej miłości poety do Maryli z Wereszczaków Puttkamerowej. Przypisano jej funkcję asymptoty porządkującej różnorodne i powikłane późniejsze życie uczuciowe Mickiewicza, rodzaj osi, w odniesieniu do której wieszcz kochał i tęsknił, zawsze do Wereszczakówny odbitej w innych kobietach. Pamięć o Maryli miała pozostać w poecie na zawsze i być czysta tak, jak rzekomo niezmącone były ich wzajemne relacje. Posiłkując się literaturą, a zwłaszcza Dziadów cz. IV, korespondencją filomatów, wspomnieniami przyjaciół, m.in. Ignacego Domeyki ${ }^{4}$ lub wielbicieli (np. Antoniego Edwarda Odyńca ${ }^{5}$ ), wykreowano mit idealnej, odwzajemnionej miłości. Późniejsze kontakty Mickiewicza z kobietami miały już w jego biografiach inny wymiar, bardziej realistyczny.

W 2009 r. na łamach „Tekstów Drugich” ukazał się mój artykuł Uwagi do biografii Maryli w świetle odnalezionego dokumentu ${ }^{6}$, dotyczący znajdującego się w wileńskiej parafii św. Jana aktu chrztu pierworodnej córki Marii

4 Są to zwłaszcza wspomnienia Domeyki (m.in. Maryla Wereszczakówna, „Ognisko Domowe", 1885, nr 57-59; List Ignacego Domeyki do Bohdana Zaleskiego (O młodości Mickiewicza), w: Księga pamiątkowa na uczczenie setnej rocznicy urodzin A. Mickiewicza (1798-1855), Warszawa 1898, t. 1; Wyjątki z nie wydanych pamiętników Ignacego Domeyki, w: Z ziemi pagórków leśnych, z ziemi łąk zielonych. Książka zbiorowa poświęcona pamięci A. Mickiewicza w 100-letniq̨ rocznicę jego urodzin, Warszawa 1899.

5 A. E. Odyniec, Wspomnienia z przeszłości opowiadane Deotymie, Warszawa 1884 a także Listy z podróży, oprac. M. Toporowski, wstęp M. Dernałowicz, t. 1-2, Warszawa 1961oraz szkic Puttkamer i Maryla. Ze wspomnień, „Przegląd Polski”, 1881, z. 10.

6 D. Samborska-Kukuć, Uwagi do biografii Maryli w świetle odnalezionego dokumentu, „Teksty Drugie", 2009, z. 3, s. 218-233. 
i Wawrzyńca Puttkamerów - Heleny Teofili Franciszki urodzonej 2 listopada 1823 r. w Wilnie 7 . Już po publikacji Uwag odnalazłam akt zgonu Heleny, która żyła tylko dwa dni, umarła 4 listopada i została pochowana na Cmentarzu Bernardyńskim w Wilnie ${ }^{8}$. Względna istotność artykułu wraz z nowym dokumentem polega na dwu czynnikach. Po pierwsze, na weryfikacji progenitury Puttkamerów, dotychczas niekompletnej, także wskutek założenia, że małżeństwo Maryli było przez kilka lat trwania wolne od zmysłowości, co miało niejako dowodzić wierności poecie. Po drugie - na wskazaniu hipotez dotyczących okoliczności napisania utworów, na które mogły wpłynąć wydarzenia z 1823 r. ciąża Puttkamerowej oraz narodziny i zgon dziecka zbieżny z czasem akcji Dziadów cz. III, gdy „Gustavus obiit - natus est Conradus”. I choć minęło dziesięciolecie, nie podjęto tropów badawczych, które wyłoniły się z faktu narodzin i śmierci dziecka Maryli.

Aby zaproponować sugestie interpretacyjne, godzi się w tym miejscu przypomnieć zasadnicze tezy Uwag. Kwestia urodzenia Heleny została przemilczana, być może również nieujawniona przez samych Puttkamerów; źródła podają bowiem, iż mieli oni tylko troje dzieci - Zofię, Stanisława, Karolinę. Zofia (późniejsza Kalinowska) - urodziła się jesienią 1825 r., po trzech latach na świat przyszedł syn - Stanisław Jan (ożeniony z Felicją z Kieniewiczów), a dopiero w 1839 r. - Karolina (wyszła za mąż za Jana Rychlewicza) $)^{9}$. O istnieniu Heleny mimochodem wspominały dzieci Puttkamerów, ale wzmianki te niczym, poza mirażem z opowieści z dawnych lat, nie były poparte. Niemniej jednak najbliższe prawdy były takie świadectwa, jak: wyznanie Karoliny Rychlewiczowej: „matka moja miała córeczkę, Helenkę, która zaraz po urodzeniu umarła,

7 Lietuvos Valstybès Istorijos Archyvas (LVIA), sygn. F604, op. 10, USC Wilno/parafia św. Jana, t. 240, nr aktu 242 z roku 1823.

8 LVIA, sygn. F604, op. 10, t. 251, USC Wilno/parafia xx. Bernardynów, k. 725, nr aktu 2757 z roku 1823 .

9 Daty według J. M. Rymkiewicza, Puttkamerowa Maria, w: Mickiewicz. Encyklopedia, red. J. M. Rymkiewicz, D. Siwicka, A. Witkowska, M. Zielińska, Warszawa 2001, s. 449; por. M. Danilewiczowa, S. Pigoń, Dialog korespondencyjny (1958-1968), oprac. Cz. Kłak, Rzeszów 1996, s. 163. Karolina urodziła się 2 maja 1839 r., została ochrzczona 17 maja, zob. Narodowe Archiwum Historyczne Białorusi w Mińsku, sygn. F262, op. 3, t. 1, USC Bieniakonie, nr aktu 45 z roku 1839. 
po dwóch tygodniach"10, oraz wspomnienie Janiny z Puttkamerów Żółtowskiej, prawnuczki Puttkamerowej, która wyjawiła, iż słyszała o jeszcze jednym, oprócz trojga, dziecku, i że była to „chyba najstarsza” córka, która zmarła wkrótce po urodzeniu ${ }^{11}$. Zbieżność tych dwu relacji nie skłoniła jednak mickiewiczologów do zajęcia się tematem, a Stanisław Pigoń wyznał wprost: „interesujące byłoby sprawdzić daty urodzenia owej zmarłej w niemowlęctwie «chyba najstarszej»; rozwiązałoby to zapewne legendę o «białym małżeństwie». Ale też mię nie ciągnie, żeby sprawdzać"12. Taka postawa - nieobca i innym, dawniejszym „biografom dworskim” - wynikająca z obaw przed odkryciami, które mogłyby podważyć zastygłe i trwałe formy, a przejawiająca się zaniechaniem, przemilczeniem czy zniekształceniem ${ }^{13}$, w jakimś sensie hamowała rozwój mickiewiczologii, zwłaszcza zaś eksploracji nowych obszarów kontekstowych ważnych nie tylko dla życiorysu poety, ale przede wszystkim dla możliwych okoliczności powstania jego dzieł.

Rzeczony dokument w jakimś sensie zweryfikował opowieść o trwającym od dnia ślubu Puttkamerów w Bieniakoniach (2/14 lutego 1821 r. - wedle nowego i starego stylu) do wyjazdu Mickiewicza z Litwy (jesień 1824 r.) rzekomym „białym małżeństwie” ukochanej poety ${ }^{14}$, mit ugruntowany na sugestiach Antoniego Odyńca i Ignacego Domeyki. Nie jest wykluczone, że w początkach związek Maryli był „biały”, ale nie trwał jednak aż tak długo, to znaczy do czasu utraty nadziei na jej związek z Mickiewiczem, co sugerowali legendotwórcy. Akt urodzenia córki Puttkamerowej pozwolił również zupełnie inaczej

10 Wspomnienia Babuni Rychlewiczowej, cz. 3, rkps BN II 10.285, cyt. za: D. Wawrzykowska-Wierciochowa, Adam i Maryla. Dzieje romantycznej miłości Adama Mickiewicza i Maryli Wereszczakówny, Warszawa 1990, s. 285.

11 Por. J. z Puttkamerów Żółtowska, Inne czasy, inni ludzie, Londyn 1959, drugie wyd. 1998.

12 S. Pigoń do M. Danilewiczowej (1 sierpnia 1960), w: Dialog korespondencyjny, s. 166167.

13 Przykładem skrajnie nienaukowego stosunku do odkryć potencjalnie zagrażających utrwalonemu paradygmatowi biograficznemu Mickiewicza jest zlekceważenie przez Józefa Kallenbacha notki służbowej z okresu kowieńskiego, zob. D. Samborska-Kukuć, Gustaw - żonaty! - o pewnym drobiazgu z Archiwum Kuratorii Wileńskiej, w: taż, Od Puttkamerów do Konopnickich. Rekonstrukcje i rewizje biograficzne, Warszawa 2016, s. 36-37.

14 T. Pini, O „białym matżeństwie” Maryli, „Ruch Literacki”, 1934, nr 3, s. 73-77. 
odczytać listy Puttkamerowej do Jana Czeczota i Tomasza Zana, opublikowane w wydanym przez Jana Czubka zbiorze Archiwum Filomatów ${ }^{15}$, zważywszy na stan brzemienny nadawczyni i związane z tym jej komentarze z tego czasu, co więcej - odpowiednio zinterpretować dziwny testament ${ }^{16}$, jaki spisała u rejenta w obecności męża w dniu 8 listopada 1823 r., tj. w kilka dni po narodzinach i zgonie dziewczynki. Wniosków z porównania czterech źródeł: aktów chrztu i zgonu, korespondencji oraz legatu jest kilka. Po pierwsze, ujawniają się uznawane dotychczas za melancholię i tęsknotę za Mickiewiczem psychiczne nastroje Marii, które w nowym kontekście wydają się depresją ciążową, niechęcią do samej siebie i do przyszłego dziecka, co poskutkowało prawdopodobnie próbą samobójczą, skoro w tak krótkim czasie po porodzie Maria została skłoniona do spisania testamentu na wyłączną korzyść dość praktycznego w tych trudnych okolicznościach małżonka. Tym samym odsłaniają się symetrycznie emocje Mickiewicza, noszące wyraźne znamiona rozczarowania Puttkamerową. Narodziny i śmierć Heleny poprzedziło aresztowanie Mickiewicza i osadzenie go w przystosowanym na więzienie klasztorze Bazylianów. Po śmierci dziecka Puttkamerowie nie powrócili do Bolcienik, zostali w Wilnie (zapewne w środę lub czwartek odbył się pogrzeb Heleny, w sobotę spisano testament). Być może w tym czasie Puttkamerowa, m.in. z Karoliną Kowalską odwiedzała Mickiewicza w więzieniu ${ }^{17}$.

Warto sprawdzić, jak te ponderabilia wpłynęły na powstające wówczas utwory? Wiersz dedykacyjny Do Marii P. został dany Puttkamerowej 12/24 maja $1823 \mathrm{r}^{18}$ jako rodzaj symbolicznego rozstania:

Maryjo, siostro moja! Nie krewnym łańcuchem, Aleśmy pobratani umysłem i duchem.

15 Archiwum Filomatów, cz. 1. Korespondencja 1815-1823, wyd. J. Czubek, Kraków 1913, t. 1-5 (zwłaszcza listy LDCXCI, DCXCI. DXXVIII, DCCXL, DCCIII, DCXCV, DCCIV, DCCXVI).

16 L. Podhorski-Okołów, Testament Maryli, w: tenże, Realia Mickiewiczowskie, Warszawa 1999, s. 206-217.

17 H. Mościcki, Wilno i Warszawa w „Dziadach” Mickiewicza. Tło historyczne trzeciej części „Dziadów”, Warszawa 1908, s. 72. Kobiety dostarczały uwięzionym głównie bieliznę i żywność.

18 M. Dernałowicz, K. Kostenicz, Kronika życia i twórczości Mickiewicza. Lata 17981824, Warszawa 1957, s. 410. 
Gdy mi dziwactwo losu i twój wyrok wzbrania, Równie święte, a milsze powtarzać nazwania: Choć innym spojrzyj okiem w przeminione lata I pamiątki kochanka przyjmij z ręki brata ${ }^{19}$.

Był to - jak go nazywa Juliusz Kleiner - dar połączony z aktem rezygnacji ${ }^{20}$. Adresatka nazywana jest „siostrą”, której „wyrok wzbrania”, by nazywać ją kochanką; te wyroki współbrzmią z „dziwactwami losu”, nieodwołalnie wyznaczając poecie rolę „brata”. Istnienie tej miłości możliwe jest już tylko w pamięci. Sztambuchowość liryku sprawia, że nie wyczuwa się w nim gniewu, urazy, żalu jest tu łagodne pogodzenie się z losem. Czy Mickiewicz wiedział już o odmiennym stanie Marii? Czy może nowe okoliczności kazały jej rozmówić się z ukochanym i rozluźnić więzi, nie zdradzając jeszcze tajemnicy małżeńskiej alkowy?

O sytuacji w rodzinie Puttkamerów Mickiewicz wiedział już na pewno w końcu czerwca, na co wskazuje jego przepełniony rozgoryczeniem list do Jana Czeczota, w którym czytamy m.in.

Wiedziałem, że jej uczucia nie tej natury, co moje, że ją straciłem; wiem, co się z nią i co się ze mną stanie, i nie uważam jej za bardzo nieszczęśliwą. [...] Życzę jej wszelkiego szczęścia najszczerzej, ale nie wszelkie może mnie tyle, ile ją, pocieszać i dlatego nie o wszystkim chcę wiedzieć. Chciałbym nawet, aby o mnie więcej nie słyszała. [...] niczym mnie nie zagniewasz; jeśli nie uweselisz, powtarzam, że nie zagniewasz. [...] Nie mam nic sobie do wyrzucenia. Jeśli ona cierpi, miała wiele i słodkich chwil; nigdy jej nie chciałem dręczyć i nie będę 21 .

List pisany był pod wpływem narastającego dystansu do „niewiernej”, która „miała wiele i słodkich chwil”. Niemało w nim zapewnień Mickiewicza o wycofaniu się, ustąpieniu z pola, zaprzestaniu adoracji. Wyczuwa się już wyraźny dystans, drwiące uznanie wyższości losu, gotowość do pożegnania się z myślą

19 A. Mickiewicz, Do Marii P. ofiarując jej drugi tomik Poezyj, w: idem, Dzieła, t. 1, Paryż-Lwów 1880, s. 197.

20 J. Kleiner, Mickiewicz, t. 1, Dzieje Gustawa, Lublin 1948, s. 339.

21 DCCXXV. Ad. Mickiewicz do Czeczota i Odyńca [list z 18/30 czerwca 1823], w: Archiwum Filomatów, cz. 1. Korespondencja 1815-1823, t. 5, s. 255-256. 
o jakiejś wspólnej przyszłości. Mickiewicz wyraźnie zamyka związany z Puttkamerową rozdział swego życia.

„Sprzeniewierzenie się" Maryli miało wpływ na powstanie kilku innych, ważniejszych tekstów. Mickiewicz, nieukrywający niechęci do życia rodzinnego (wszak to spod jego pióra wyszło wyznanie poczynione Franciszkowi Malewskiemu: „gdzie jest opis szczęścia, życia familijnego równie mnie oburza, jak widok małżeństw, dzieci; jest to jedyna moja antypatia"22), uznał nadzieje pokładane w związku z Puttkamerową za rozwiane, a siebie za oszukanego. Czy to właśnie wtedy powstał najsłynniejszy bodaj liryk miłosny Mickiewicza Do $M^{\star}$ (Precz z moich oczu...)? Datacja pod nim to rok 1823. Czy można go teraz odczytać nie jako żałosną skargę odrzuconego, ale ironiczne pożegnanie kobiety, która skazana zostaje na bolesne rozpamiętywanie swojej przewiny? Ale jakiej właściwie przewiny? Złamania ślubów czystości złożonych Mickiewiczowi? Czy naprawdę dwudziestosześcioletni mężczyzna wierzył w realizację takich „ślubów"? Po co zresztą miałyby być złożone? Z czyjej inicjatywy? Czy z egzaltacji Puttkamerowej, kreującej się na bezcielesną Moore'owską Peri? Trudno uwierzyć, że były to eksperymenty mistyczne dwojga zakochanych, prędzej teatralne gesty, będące mimikrą trójkąta miłosnego Lotta-Werter-Albert. Inna rzecz, że Mickiewicz mógł wierzyć, że skoro urodzili się tego samego dnia - 24 grudnia (Puttkamerowa była dokładnie o rok młodsza), to są sobie przeznaczeni. Każe przecież wyznać Gustawowi:

[...] nas Bóg urządził ku wspólnemu życiu, Jednakowa nam gwiazda świeciła w powiciu.

Równi, choć różnych zdarzeń wykształceni ciekiem,

Postawą sobie bliscy, jednostajni wiekiem,

Ten sam powab we wszystkim, toż samo niechcenie,

Też same w myślach składnie i w czuciach płomienie.

Gdy nas wszędzie tożsamość łączy niedościgła,

Bóg osnuł przyszłe węzły,

a tyś je rozstrzygła! ${ }^{23}$

22 List Adama Mickiewicza do Franciszka Malewskiego z listopada 1822, w: A. Mickiewicz, Dzieła. Wydanie Rocznicowe, t. XIV: Listy. Część pierwsza: 1815-1829, oprac. M. Dernałowicz, E. Jaworska, M. Zielińska, Warszawa 1998, s. 245.

23 A. Mickiewicz, Dziady, cz. IV, w: tenże, Dzieła, t. 2, s. 226. 
Czy Mickiewicz postawą Maryli, posłusznej bezdyskusyjnym zasadom małżeńskim, aż tak się rozczarował? Zapewne tak, a Puttkamerowa zdawała sobie z tego sprawę, pisząc do Czeczota smutny, zaprawiony ironią list:

Ja całkiem zezwierzęcałam, zapomniałam myśleć i mówić, nie żyję już moralnie. Żałuję bardzo przeszłości, porównując ją ze stanem obecnym. Zniżyłam się nadto do ziemi; zamiast latania po sferach smażę konfitury i zbieram czarne jagody w lesie. A tak, chociaż straciłam i wyrzekłam się przyjemności, jakich doznawałam w życiu spirytualnym, ale zyskałam w opinii Pana, bo mogę być policzoną w rzędzie gospodyń, Boga się bojących ${ }^{24}$.

Warto w tym kontekście przypomnieć sens strof Nowego Roku, wiersza pisanego w więzieniu, a rekapitulującego nieodwołalnie zamknięty etap w życiu poety:

Chorowałem, marzyłem, latałem i spadam;

Marzyłem boską różę, bliski jej zerwania

Zbudziłem się, sen zniknął, róży nie posiadam,

Kolce w piersiach zostały. - Nie żądam kochania ${ }^{25}$.

A więc jednak rozżalenie i rezygnacja.

Warto zwrócić uwagę, iż symptomatyczna jest zbieżność w czasie przyjścia na świat córki Maryli i śmierci Gustawa (narodzin Konrada). Czy zbieżność ta jest wynikiem przypadku, bo - jak się zwykło uważać - Mickiewiczowi chodziło o Dzień Zaduszny związany z pogańskim obrzędem tzw. dziadów? A może jednak ten właśnie dzień oznaczać miał dla poety koniec młodzieńczych złudzeń, koniec wiary w platoniczną miłość i braterstwo dusz? W kontekście rozważań o urodzeniu córki Maryli mogą one nabrać nowego znaczenia, choćby drugorzędnego. Jeśli tak, zrozumiała będzie literacka „zemsta” poety, którą ostro wyartykułował już w Dziadach cz. IV (m.in. w monologach Gustawa: „tak ciebie oślepiło złoto! I honorów świecąca bańka, wewnątrz pusta!"26), dlatego rzuca na nią przekleństwo: „niech ją własna pamięć goni, niech ją sumienia sztylety

24 DCCXL. Maryla do Czeczota [list z 27 lipca/8 sierpnia 1823], w: Archiwum Filomatów, t. 5, s. 290.

25 A. Mickiewicz, Nowy Rok, w: tenże, Dzieła, t. 1, s. 343.

26 A. Mickiewicz, Dziady, cz. IV, s. 226. 
ranią!"27. Wydaje się, że problem tej „zdrady” Mickiewicz długo przepracowywał, dokonując autoterapii literackiej.

Rozterki Mickiewicza wpisane w powyższe teksty rozumiane były jako warianty kreacji werterowskiej i imaginatywnej. Ich powodem (w nadzwyczaj uproszczonej wersji) miał być wybór Maryli, która odrzuciła zakochanego w niej Mickiewicza. Tymczasem, rozpoznawszy ich biograficzny kontekst, bardziej zawikłany, mogą zdradzać skonkretyzowane znamiona rozczarowań. Czy Mickiewicz przeżywał zawód Marylą już jako Puttkamerową, skoro w kilku tekstach wspominał ją z imienia, oskarżając o małostkowość czy interesowność? Dzieje się tak nawet w balladzie To lubię, w której bohaterka - Maryla - zostaje przedstawiona jako kobieta nieczuła i zimna, sprowadzająca śmierć na rozmiłowanego w niej młodzieńca. W kontekście tych sugestii interpretacyjnych mocniej niż dotychczas wybrzmiewają słowa Marii Czapskiej, która pisała, że czar „nadludzkiej dziewicy” prysł z chwilą, kiedy Mickiewicz przekonał się, że jest żoną ${ }^{28}$. Czy aż tak bardzo nie mógł wybaczyć jej Helenki - owocu małżeńskiego pożycia?

„Odnalezienie" Heleny Puttkamerówny pozwoliło mi w Uwagach dokonać reasumpcji listów filomatów, które bez kontekstu, tj. wiedzy o stanie brzemiennym Maryli, były odczytywane inaczej, w niniejszym artykule pozyskana wiedza stała się podstawą propozycji interpretacyjnych, wzbogacenia o nowe okoliczności powstania kilku utworów Mickiewicza. Być może kryją się w nich nie tylko rozterki duchowe, powstałe w imaginacji poety, ale ślady konkretnych zdarzeń, o których nie mógł zapomnieć.

Streszczenie: $\mathrm{W}$ procesie formowania biografii mickiewiczowskiej, mającej w jakiejś części gotową formę mityczną ukształtowaną przez syna poety i badaczy-apologetów, zniszczeniu (lub przemilczeniu) uległa część dokumentów, redukując ważne konteksty. Artykuł przywołuje taki kontekst, dotyczący wileńsko-kowieńskiego okresu życia poety, a przede wszystkim jego rozterek psychicznych towarzyszących rozstaniu z Marią z Wereszczaków Puttkamerową.

Jej obecność w biografii i dziele Adama Mickiewicza uwarunkowana była silnym obustronnym afektem; postrzegana jest przez badaczy jako arcywzorzec romantycznej miłości, rodzimy paradygmat werteryczny. Źródłem legend i mitów nagromadzonych wokół znajomości poety z Puttkamerową, nierzadko wyprowadzanych z tekstów

27 Ibidem, s. 228.

28 M. Czapska, Szkice mickiewiczowskie, Londyn 1963, s. 55. 
literackich, były domysły. Odnalezione dokumenty, czyli akt urodzenia i zgonu pierworodnej córki Puttkamerów - Heleny, mogą przyczynić się do wzbogacenia interpretacji korespondencji oraz odczytania niektórych utworów postrzeganych przez drobne pryzmaty z biografii poety.

Słowa kluczowe: Adam Mickiewicz, Maria z Wereszczaków Puttkamerowa, liryka miłosna, Dziady cz. IV i III.

\section{Bibliografia}

\section{Źródła}

Lietuvos Valstybės Istorijos Archyvas (LVIA), sygn. F604, op. 10, t. 240 i 251.

Narodowe Archiwum Historyczne Białorusi w Mińsku, sygn. F262, op. 3, t. 1.

\section{Opracowania}

Archiwum Filomatów, cz. 1. Korespondencja 1815-1823, wyd. J. Czubek, Kraków 1913, t. 1-5. Czapska M., Szkice mickiewiczowskie, Londyn 1963.

Danilewiczowa M., Pigoń S., Dialog korespondencyjny (1958-1968), oprac. Cz. Kłak, Rzeszów 1996.

Dernałowicz M., Kostenicz K., Kronika życia i twórczości Mickiewicza. Lata 1798-1824, Warszawa 1957.

Domeyko I., Maryla Wereszczakówna, „Ognisko Domowe”, 1885, nr 57-59, s. ???

Kleiner J., Mickiewicz, t. 1: Dzieje Gustawa, Lublin 1948, s. 339.

Księga pamiątkowa na uczczenie setnej rocznicy urodzin A. Mickiewicza (1798-1855), t. 1, Warszawa 1898.

Mickiewicz A., Dzieła, t. 1-2, Paryż-Lwów 1880.

Mickiewicz A., Dzieła. Wydanie Rocznicowe, t. XIV: Listy. Część pierwsza: 1815-1829, oprac. M. Dernałowicz, E. Jaworska, M. Zielińska, Warszawa 1998.

Miłosz C., O podróżach w czasie, wybór i oprac. J. Gromek, Kraków 2004.

Mościcki H., Wilno i Warszawa w „Dziadach” Mickiewicza. Tło historyczne trzeciej części „Dziadów”, Warszawa 1908.

Nasiłowska A., Płaszcz Konrada, „Teksty Drugie”, 1993, z. 2, s. 1-4.

Odyniec A. E., Listy z podróży, t. 1-2, oprac. M. Toporowski, wstęp M. Dernałowicz, Warszawa 1961.

Odyniec A. E., Puttkamer i Maryla. Ze wspomnień, „Przegląd Polski”, 1881, z. 10.

Odyniec A. E., Wspomnienia z przeszłości opowiadane Deotymie, Warszawa 1884.

Pini T., O „białym małżeństwie” Maryli, „Ruch Literacki”, 1934, nr 3, s. 73-77. 
Podhorski-Okołów L., Testament Maryli, w: L. Podhorski-Okołów, Realia Mickiewiczowskie, Warszawa 1999, s. 206-217.

Rymkiewicz J. M., Puttkamerowa Maria, w: Mickiewicz. Encyklopedia, red. J. M. Rymkiewicz, D. Siwicka, A. Witkowska, M. Zielińska, Warszawa 2001, s. 449.

Ryszka D., Poeta o poecie. Mickiewicz na warsztacie Rymkiewicza, w: W cieniu Mickiewicza, red. J. Lyszczyna, M. Bąk, Katowice 2006.

Samborska-Kukuć D., Gustaw - zonaty! - o pewnym drobiazgu z Archiwum Kuratorii Wileńskiej, w: D. Samborska-Kukuć, Od Puttkamerów do Konopnickich. Rekonstrukcje i rewizje biograficzne, Warszawa 2016, s. 36-37.

Samborska-Kukuć D., Uwagi do biografii Maryli w świetle odnalezionego dokumentu, „Teksty Drugie”, 2009, z. 3, s. 218-233.

Wawrzykowska-Wierciochowa D., Adam i Maryla. Dzieje romantycznej miłości Adama Mickiewicza i Maryli Wereszczakówny, Warszawa 1990.

Z ziemi pagórków leśnych, z ziemi łąk zielonych. Książka zbiorowa poświęcona pamięci

A. Mickiewicza w 10o-letnią rocznicę jego urodzin, Warszawa 1899.

Żółtowska z Puttkamerów J., Inne czasy, inni ludzie, Londyn 1959, drugie wyd. 1998. 